\title{
Mutations within or upstream of the basic helix-loop-helix domain of the TWIST gene are specific to Saethre-Chotzen syndrome
}

\author{
Vincent EI G houzzi, E lisabeth Lajeunie, M artine Le M errer, Valérie Cormier-D aire, \\ $\mathrm{D}$ ominique R enier, A rnold M unnich and Jacky Bonaventure
}

U nité de R echerches sur les H andicaps G énétiques de l'E nfant, Institut N ecker, Paris, France

\begin{abstract}
Saethre-Chotzen syndrome (ACS III) is an autosomal dominant craniosynostosis syndrome recently ascribed to mutations in the TWIST gene, a basic helix-loop-helix (b-HLH) transcription factor regulating head mesenchyme cell development during cranial neural tube formation in mouse. Studying a series of 22 unrelated A CS III patients, we have found TWIST mutations in 16/22 cases. Interestingly, these mutations consistently involved the b-HLH domain of the protein. Indeed, mutant genotypes included frameshift deletions/insertions, nonsense and missense mutations, either truncating or disrupting the b-H LH motif of the protein. This observation gives additional support to the view that most ACS III cases result from loss-of-function mutations at the TWIST locus. The P250R recurrent F G F R 3 mutation was found in 2/22 cases presenting mild clinical manifestations of the disease but 4/22 cases failed to harbour TWIST or F G F R 3 mutations. Clinical re-examination of patients carrying TWIST mutations failed to reveal correlations between the mutant genotype and severity of the phenotype. Finally, since no TWI ST mutations were detected in $\mathbf{4 0}$ cases of isolated coronal craniosynostosis, the present study suggests that TWIST mutations are specific to SaethreChotzen syndrome.
\end{abstract}

Keywords: Saethre-Chotzen syndrome; coronal craniosynostosis; TWIST and F G F R 3 genes; bH LH transcription factor

\section{Introduction}

Saethre-Chotzen syndrome (ACS III) is an autosomal dominant craniosynostosis syndrome characterised by craniofacial and limb abnormalities, including variable and asymmetrical craniosynostosis, lid ptosis, small ears

Correspondence: Jacky B onaventure, INSE R M U 393, Hôpital Necker, 149 rue de Sèvres, 75743 Paris cedex 15, France. Fax: 331473485 14; E-mail: bonavent@necker.fr

R eceived 11 February 1998; revised 18 M ay 1998; accepted 8 June 1998 with prominent crura, cutaneous syndactyly of the second interdigital space and broad halluces. A dditional features including hypertelorism, maxillary hypoplasia and strabismus have been reported. ${ }^{1}$ Linkage analyses and fluorescent in situ hybridisation experiments in affected individuals carrying balanced translocations resulted in the mapping of ACS III to chromosome $7 \mathrm{p} 21 .^{2-6}$ Recently, ACS III has been ascribed to mutations in the basic helix-loop-helix (b-H LH) domain of the TWIST gene. ${ }^{7,8}$ This transcription factor plays a key role in regulating mesodermal differentiation and myogenesis in Drosophila. ${ }^{9,10}$ In 
vertebrates, this factor is apparently involved in negative control of cellular determination and in differentiation of several cell lineages including myogenesis, neurogenesis and osteogenesis. ${ }^{11-14}$

The putative interactions between TWIST and Fibroblast G rowth Factor R eceptors (F G FR s) via a common signalling pathway are supported by the recent observation that several familial cases of ACS III-like craniosynostosis syndromes and sporadic cases originally diagnosed as ACS III, harboured the recurrent P250R FG FR 3 mutation in the extracellular region of the receptor. ${ }^{15-18} \mathrm{H}$ ere we report on 16 additional TWIST mutations (including 11 novel mutations) in typical ACS III patients. All these mutations are expected to truncate or disrupt the b-HLH domain of the protein. By contrast, patients harbouring the P250R FGFR 3 mutation had a less severe condition. The absence of TWIST mutations in 40 cases of nonsyndromic coronal craniosynostosis further suggests that TWIST mutations are specific to Saethre-Chotzen syndrome.

\section{Patients and Methods}

\section{Patients}

A series of 22 patients with syndromic craniosynostosis clinically diagnosed as Saethre-Chotzen syndrome were referred to and treated at $\mathrm{H}$ ôpital des $\mathrm{E}$ nfants-M alades, Paris. In addition to craniosynostosis manifesting as brachycephaly, plagiocephaly or oxycephaly, at least three of the following criteria were retained for inclusion in the A CS III group:

i) lid ptosis

ii) abnormal ear with prominent crura

iii) cutaneous syndactyly of the second interdigital space

iv) broad or duplicated halluces.

Coronal craniosynostosis was unilateral in 8/22 cases ( 5 rightsided and 3 left-sided plagiocephaly) and bilateral in 9/22 cases (brachycephaly). Five cases had an associated involvement of the sagittal sutures (oxycephaly). The metopic suture was also affected in four patients with either unilateral (2 cases) or bilateral coronal synostosis (2 cases). A dditional limb abnormalities included mild 3-5 cutaneous syndactyly (5 cases) and brachydactyly ( 3 cases). Intrafamilial variability in limb involvement (with or without duplicated big toe) was noted. 0 ther facial abnormalities were also observed, namely lowset frontal hairline ( 6 cases), epicanthus ( 6 cases), hypertelorism ( 5 cases) and strabismus ( 4 cases). M ost patients had an IQ from 90 to 120 and three individuals had an obvious developmental delay (IQ: 50-70) without any evidence of chromosomal rearrangement. No increase in paternal age was found.
A second group of 40 patients with non-syndromic coronal craniosynostosis was investigated for mutations in the TWIST gene.

\section{DNA Analyses}

Blood samples were obtained with the written consent of the patients and non-affected relatives. The whole coding sequence of the TWIST gene was amplified in two overlapping fragments of 461 and 371 nt respectively by using two sets of primers - first set: forward primer $5^{\prime}$ GCAAGCGCGGCAAGAAGTCT 3'; reverse primer 5' GGGGTGCAGCGGCGCGGTC 3'; second set: forward primer 5' GAGGCGCCCCGCTCTTCTCC 3'; reverse primer 5' CCTCGTAAGACTGCGGACTC 3'. Genomic DNA was PCR amplified using 15 pmoles of each primer, $200 \mu \mathrm{m}$ dNTP, 5\% DMSO and 1 U Taq polymerase in a final volume of $50 \mu \mathrm{l}$. A mplified fragments were analysed by single strand conformation polymorphism (SSCP) on Hydrolink MDE gels after digestion of the $461 \mathrm{nt}$ fragment by restriction enzyme Rsa I. A mplification products showing abnormal patterns of migration were reamplified and sequenced by using the fluorescent dideoxy terminator method on an automatic sequencer $A B I$. When insertions or deletions were detected by direct sequencing of PCR products, the mutant and normal alleles were cloned into the vector $\mathrm{PCR} 3$ using the TA cloning kit (In vitrogen); individual clones were randomly sequenced. In order to study the unique intron, the following primers were designed: forward $5^{\prime}$ CGGAGCCCCCCACCCCCT 3' $^{\prime}$ reverse 5' CTGTCCATTTTCTCCTTCTCTG 3'. A $609 \mathrm{bp}$ amplimer was generated and submitted to SSCP analysis after restriction digestion, then to direct sequencing. Two other primers (forward 5' G GTTTGGGAGGACGAATTGT 3'; reverse 5' GCTCTTCCTCGCTGTTGCTC 3') were chosen for sequencing of the promoter region. The non-translated exon 2 was amplified using two sets of overlapping primers - first set: forward 5' CCTA AACA ATA ACCGACTCC 3'; reverse 5' GTTCCTCTGATTGTTACCATT 3'; second set: forward 5' CAAGAGGTCGTGCCAATCAG $3^{\prime}$; reverse $5^{\prime}$ CCAAATCTAAGGTTCTCTA A ATT 3'.

R esequencing of the TWIST gene revealed discrepancies with respect to the previously reported sequence ${ }^{19}$ (accession number X 99268). In agreement with Howard et al, ${ }^{8}$ the TWIST protein is encoded by 202 aminoacids (instead of 206). Mutations previously reported $^{7}$ were renumbered accordingly.

To study the FG FR 3 gene, primers located in introns 6 and 7 were used to amplify a 337 nt fragment ${ }^{20}$ which was separated on 4\% metaphor gels (FMC) following digestion with $\mathrm{N} \mathrm{ci} \mathrm{I} \mathrm{(New} \mathrm{E} \mathrm{ngland} \mathrm{B} \mathrm{iolabs).} \mathrm{D} \mathrm{etection} \mathrm{of} \mathrm{an} \mathrm{additional}$ $151 \mathrm{nt}$ band was followed by sequence analysis of the mutant DNA.

\section{Results}

\section{Mutation Analysis in the TWIST Gene}

A total of 22 previously unreported ACS III patients were screened for mutations in the TWIST gene. SSCP analysis of the PCR fragment encompassing the b-HLH domain and adjacent sequences revealed an abnormal pattern of migration in $16 / 22$ patients ( six familial forms 
and ten sporadic cases) and sequence analyses led to identification of 16/16 mutant genotypes, including nonsense mutations (8/16), a frameshift insertion $(1 / 16)$, frameshift deletions (3/16) expected to either truncate or elongate the TWIST protein and missense mutations (4/16; Figure 1). Nonsense mutations and frameshift deletions/insertion consistently occurred within (7/12) or upstream to the b-H LH domain of the protein in our series (5/12). M issense mutations affected highly conserved residues in the loop (3/4) or helix 2 (1/4). In 6/22 ACS III patients (three familial forms and three sporadic cases), no mutations in exon 1 were found despite SSCP and sequence analyses. $M$ oreover, no base changes were found in the promoter region, in untranslated exon 2 or in the splice junctions of the TWIST gene. However, in two familial cases (2/6), the P250R FGFR 3 mutation was present and segregated with the disease (result not shown).

On the other hand, screening 40 cases of nonsyndromic coronal craniosynostosis failed to detect TWIST mutations.

\section{Genotype-Phenotype Correlations in ACS III Patients}

In an attempt to correlate mutant genotypes with clinical phenotypes, ACS III patients harbouring TWIST mutations were re-examined clinically. B oth the patients reported by EI Ghouzzi et $\mathrm{al}^{7}$ and those reported in this study were investigated and split into three groups, based on

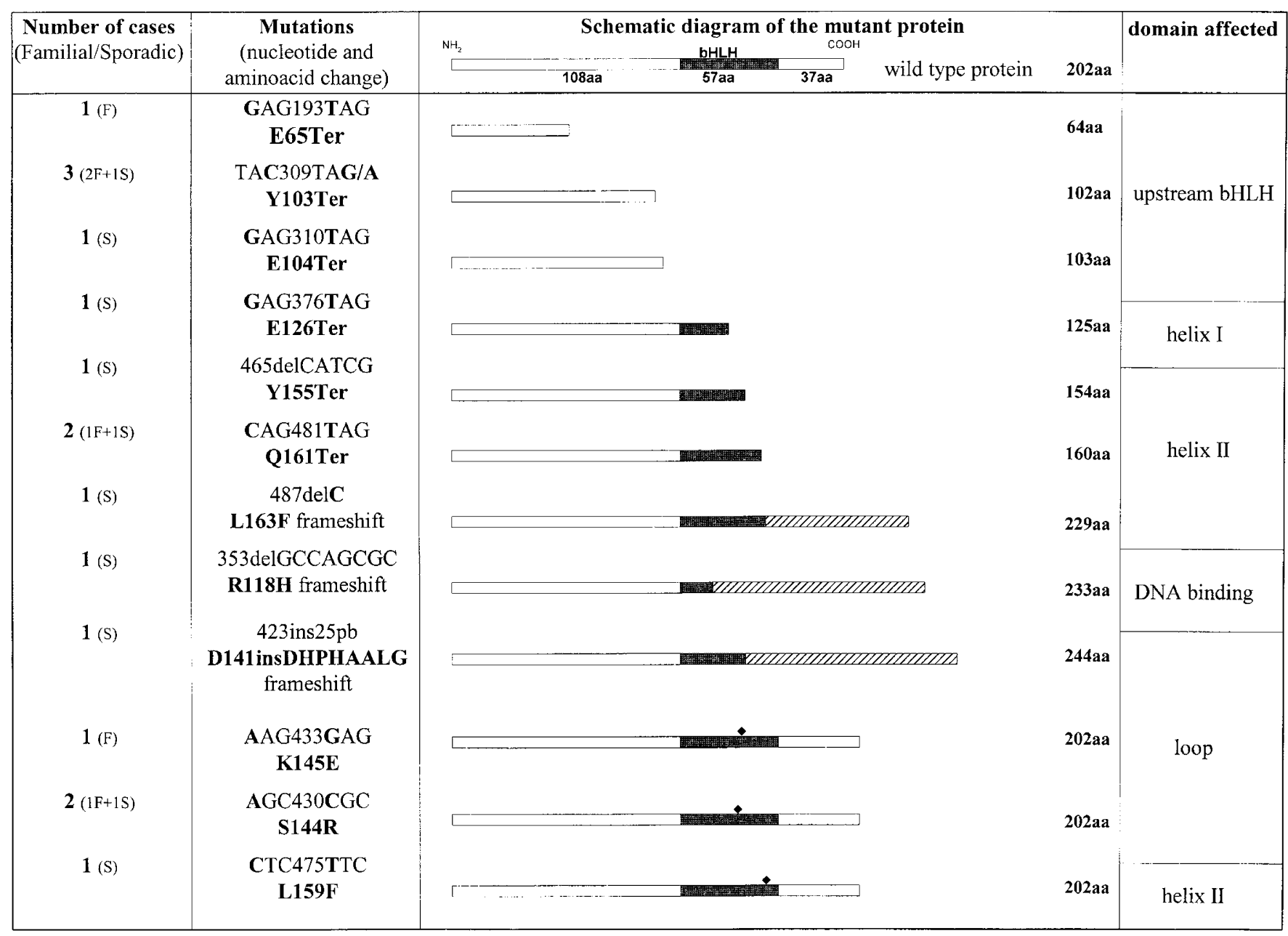

Figure 1 TWIST gene mutations in 16 patients with Saethre-C hotzen syndrome. P remature termination codons (Ter) are expected to truncate the TWIST protein which would lack part or all the b-H L H domain. Frameshift deletions (del) or insertion (ins) are predicted to either elongate the TWIST protein via disruption of the reading frame (hatched boxes) or truncate the protein. Putative sizes of mutant proteins are given ( $a a=$ aminoacids). Positions of missense mutations are indicated by black diamonds. 
i) mutations truncating or disrupting the TWIST protein (nonsense mutations, frameshift deletions/insertions),

ii) in-frame insertions of 7 aminoacids in the interhelical loop

iii) missense mutations retaining the $\mathrm{b}-\mathrm{H} \mathrm{LH}$ domain (Table 1).

It appeared that all affected individuals had ptosis, small round ears and/or crus helicis and 2-3 cutaneous syndactyly regardless of the molecular subtypes and no clinical differences between the three groups were noted. It is worth noting that patients who failed to harbour TWIST or FGFR 3 mutations were clinically indistinguishable from those carrying TWIST mutations, whilst patients carrying the P250R FGFR 3 mutation had a less severe phenotype, including moderate ptosis, normal size ears and mild cutaneous syndactyly 2-3 (Figure 2).

\section{Discussion}

Based on the analysis of a series of 22 unrelated Saethre-Chotzen patients, the present study shows that most mutations involved the b-HLH domain of the TWIST gene in ACS III (16/22). The newly identified TWIST mutations consisted in nonsense, missense mutations and frameshift deletions/insertions in the b-HLH domain. A total of 40 TWIST gene mutations (summarized in Figure 3) have been hitherto identified in ACS $\mathrm{III}^{7,8,17}$ (and this study) and some of them proved to be recurrent. In particular, the rate of $\mathrm{C}$-toG/A transversions at nucleotide 309 looked unexpectedly high (10\%). Nonsense mutations $(37.5 \%)$ and frameshift deletions or insertions $(12.5 \%)$ were predicted to either truncate or disrupt the b-H L H motif of the protein, whereas missense mutations in the HLH region (25\%) and the 7 aminoacids in frame insertions (20\%) most likely altered the secondary/tertiary structure of the b-HLH domain thus hampering dimerisation. These features along with the phenotypic expression of $\mathrm{M}$-Twist null heterozygous mutations in mice ${ }^{7}$ support the view that haploinsufficiency or loss of function at the TWIST locus are the major mechanisms of A CS III. A long these lines, it is worth remembering that Waardenburg syndrome type II is also caused by loss-of-function mutations of the MITF gene, a transcriptional factor with a b-HLH domain and a leucine zipper activity. ${ }^{21}$

Yet the molecular mechanism underlying the disease remains questionable. Since TWIST belongs to the tissue-specific class B b-H L H proteins, one can hypothesise that truncated TWIST proteins either fail to form stable homodimers or heterodimerise with $\mathrm{E}$ proteins (the product of $E 2$ genes), a group of widely expressed class $A$ b-HLH proteins which preferentially dimerise with class B b-H L H proteins. ${ }^{22,23}$ Point mutations in the basic region of E 47 were shown to prevent DNA binding without altering heterodimer formation. ${ }^{24} \mathrm{Con}$ sequently, the presence of missense mutations at equivalent residues in the DNA-binding domain of TWIST (in 2/40 patients) suggests a dominant negative effect in these two cases. ${ }^{25}$ However, the recent

Table 1 Summary of clinical findings in affected individuals carrying TWIST mutations

\begin{tabular}{|c|c|c|c|c|c|}
\hline \multirow[b]{2}{*}{ Clinical features } & \multicolumn{3}{|c|}{$\begin{array}{l}\text { Patients with mutations } \\
\text { disrupting the } b-\mathrm{HLH} \text { domain }\end{array}$} & \multirow{2}{*}{$\begin{array}{l}\text { Patients with } \\
\text { missense mutations* } \\
\text { this study }\end{array}$} & \multirow{2}{*}{$\begin{array}{l}\text { Patients with } \\
\text { in frame duplications } \\
\text { previous } \\
\text { study7 }\end{array}$} \\
\hline & this study & $\begin{array}{l}\text { previous } \\
\text { study }\end{array}$ & total & & \\
\hline Plagiocephaly & $5 / 12$ & $2 / 3$ & $7 / 15$ & $1 / 4$ & $0 / 3$ \\
\hline B rachycephaly & $4 / 12$ & $0 / 3$ & $4 / 15$ & $3 / 4$ & $3 / 3$ \\
\hline Oxycephaly & $3 / 12$ & $1 / 3$ & $4 / 15$ & $0 / 4$ & $0 / 3$ \\
\hline Ptosis & $12 / 12$ & $3 / 3$ & $15 / 15$ & $4 / 4$ & $3 / 3$ \\
\hline E picanthus & $5 / 12$ & $0 / 3$ & $5 / 15$ & $0 / 4$ & $0 / 3$ \\
\hline H ypertelorism & $3 / 12$ & $0 / 3$ & $3 / 15$ & $2 / 4$ & $1 / 3$ \\
\hline Low front hairline & $4 / 12$ & $1 / 3$ & $5 / 15$ & $2 / 4$ & $2 / 3$ \\
\hline Small ears & $10 / 12$ & $3 / 3$ & $13 / 15$ & $4 / 4$ & $2 / 3$ \\
\hline E ar crura & $11 / 12$ & $2 / 3$ & $13 / 15$ & $4 / 4$ & $3 / 3$ \\
\hline Syndactyly 2-3 (hand) & $12 / 12$ & $3 / 3$ & $15 / 15$ & $4 / 4$ & $3 / 3$ \\
\hline Broad big toe & $9 / 12$ & $3 / 3$ & $12 / 15$ & $3 / 4$ & $3 / 3$ \\
\hline B rachydactyly & $1 / 12$ & $1 / 3$ & $2 / 15$ & $0 / 4$ & $0 / 3$ \\
\hline M ental retardation & $1 / 12$ & $1 / 3$ & $2 / 15$ & $0 / 4$ & $0 / 3$ \\
\hline
\end{tabular}

\footnotetext{
*O ne familial case with missense mutation (L 131P) was not available for detailed clinical examination.
} 

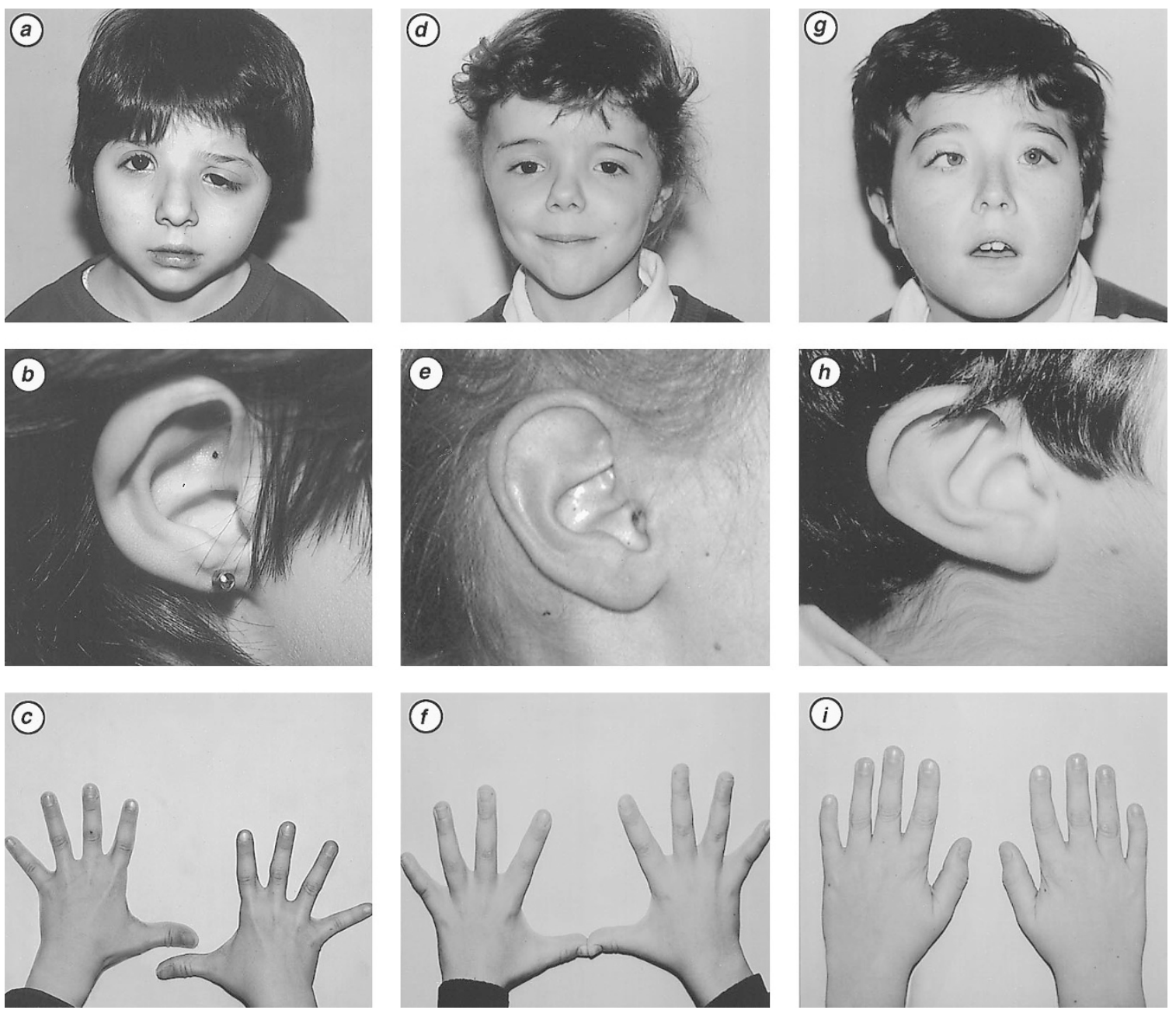

Figure 2 Post-operative facial appearance and associated clinical features in three representative affected patients (two sporadic cases (a-c; g-i) and one familial form (d-f)). a-c) Eight year-old typical ACS III patient harbouring the R 118H del8bp TW IST mutation with facial dysmorphism and asymmetrical ptosis (a), small and round ear with prominent crus helicis (b), 2-3 cutaneous syndactyly (c). d-f) Seven year-old girl originally diagnosed as having Saethre-C hotzen syndrome and carrying the P 250R FG FR 3 mutation with mild ptosis and slight facial asymmetry (d), normal size ear with crus helicis (e), mild 2-5 finger cutaneous syndactyly (f). $g$-i) Twelve year-old patient with typical Saethre-Chotzen syndrome failing to harbour TWIST or FGFR 3 mutations, showing facial dysmorphism, asymmetrical ptosis and strabismus (g), small ear with crus helicis (h), 2-4 finger cutaneous syndactyly (i).

demonstration that in mouse cells $M$-Twist interacts with myogenic b-HLH proteins through its DNA binding domain and that conversion of the conserved arginine residues into alanine abolished this interaction ${ }^{14}$ suggests that mutations in the basic region of the human TWIST gene at equivalent positions could produce a non-functional protein unable to interact with osteogenic b-HLH proteins. Hence, we speculate that loss of TWIST protein function in bone cells could induce premature differentiation of stem cells into osteoblasts at the suture level.

On the other hand, it is worth noting that 4/22 ACS III patients failed to harbour TWIST mutations in our series. O ne can speculate that these patients carry short scale deletions flanking the TWIST gene and downregulating its expression via a positional effect, especially as a translocation deletion located $5 \mathrm{~kb}$ downstream from the TWIST gene has been recently described in association with mild ACS $11{ }^{26}{ }^{26}$ Interestingly, such a positional effect has been previously reported for PAX 6 in aniridia, ${ }^{27}$ GLI 3 for G reig syndrome ${ }^{28}$ and SOX 9 for campomelic dysplasia. ${ }^{29}$

R e-examination of clinical symptoms in our A CS III patients carrying TWIST mutations revealed that they consistently presented a ptosis with 2-3 syndactyly of the hands and abnormal ears (round and small with 


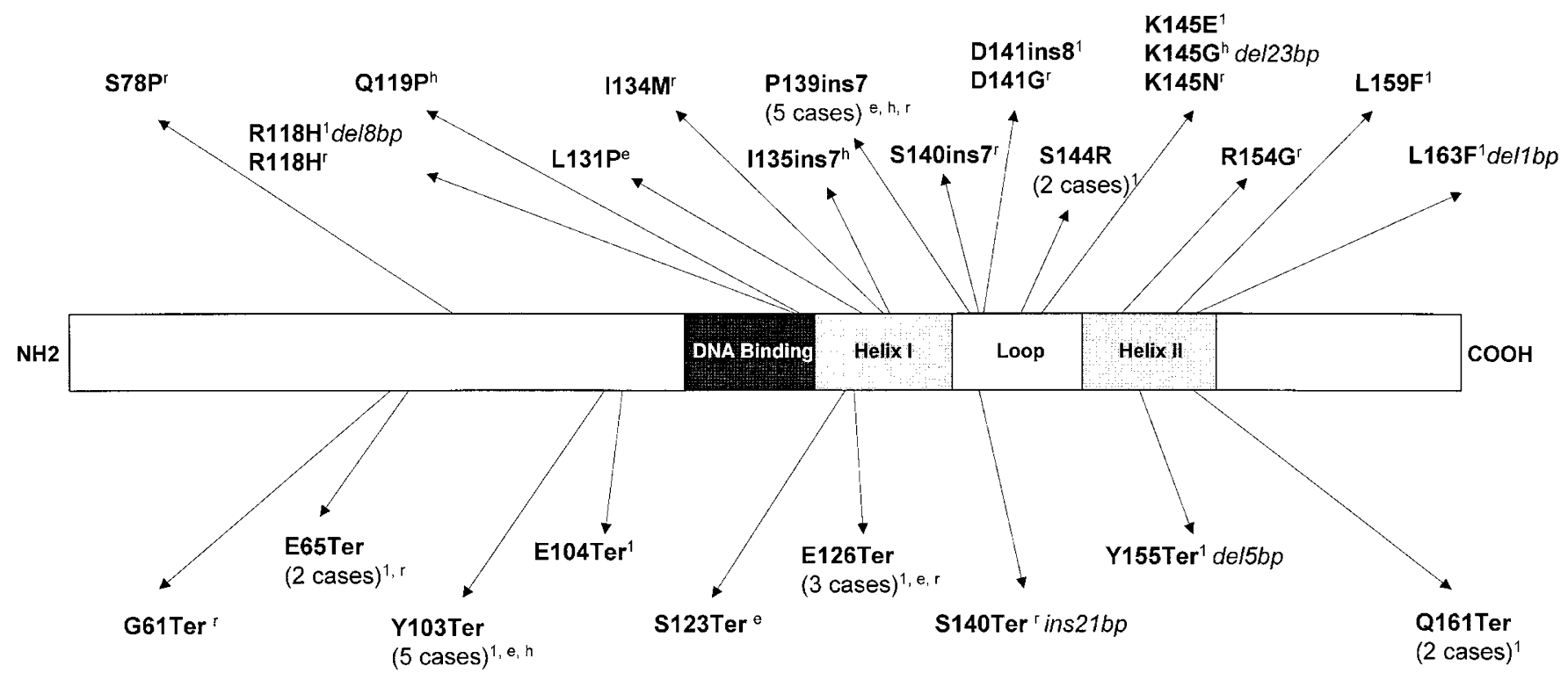

Figure 3 Summary of hitherto identified TWIST mutations in familial and sporadic cases of Saethre-Chotzen syndrome. Schematic representation of the TWIST protein showing the location of mutations reported in ${ }^{1}$ this study, ${ }_{1}, \mathrm{EI} \mathrm{G}_{\text {houzzi }}$ et al ${ }^{7}{ }^{\mathrm{h}} \mathrm{H}$ oward et al, ${ }^{8}$ ${ }^{\mathrm{r}}$ Rose et al. ${ }^{17}$ Numbers in parentheses correspond to recurrent mutations.

frequent crus helicis) regardless of the molecular subtype. Broad or duplicated halluces were otherwise frequent, while hypertelorism, epicanthus, lowset frontal hairline and brachydactyly were inconstant. Interestingly, no correlation between clinical phenotypes and mutant genotypes at the TWIST locus could be found in our series suggesting that most mutations result in non-functional proteins.

Two patients originally diagnosed as Saethre-Chotzen syndrome harboured the recurrent P250R mutation in FGFR 3 as previously reported. ${ }^{16,17}$ On clinical re-examination, both patients appeared to have a milder phenotype than typical ACS III individuals. Y et the phenotypical overlap of patients with TWIST and P250R FGFR 3 mutations further supports the view that the two factors are involved in a common signalling pathway during craniofacial and limb development, ${ }^{7,8}$ especially as a drosophila homolog of FGFRs (DFR-1/heartless) acts as a target for the TWIST protein during D rosophila mesodermal differentiation. ${ }^{30}$ Finally, since no TWIST mutations were found in a large series of 40 non-syndromic coronal craniosynostoses, it appears that TWIST mutations are specific to Saethre-C hotzen syndrome. Considering that diagnosing ACS III is frequently difficult, owing to clinical variability and phenotypic overlap with coronal craniosynostoses, the present study suggests that screening for both TWIST and the P250R FGFR 3 mutation is required for accurately diagnosing this condition.

\section{Acknowledgements}

We are thankful to the family members for their participation in this study. This work was supported by the A ssociation Française contre les M yopathies (A FM).

\section{References}

1 Reardon W, Winter RM: Saethre-Chotzen syndrome. J Med G enet 1994; 31: 393-396.

2 Brueton $L A$, van $H$ erweden $L$, Chotai $K A$, Winter $R M$ : The mapping of a gene for craniosynostosis; evidence for linkage of the Saethre-Chotzen syndrome to distal chromosome 7p. J M ed G enet 1992; 29: 681-685.

3 R ose CSP, K ing A A, Summers D et al: L ocalization of the genetic locus for Saethre-Chotzen syndrome to a $6 \mathrm{cM}$ region of chromosome 7 using four cases with apparently balanced translocations at 7p21.2. Hum Mol G enet 1994; 3: $1405-1408$.

4 Lewanda A F, Cohen M M J r, Jackson CE et al: Genetic heterogeneity among craniosynostosis syndromes: mapping the Saethre-Chotzen syndrome locus between D 7S513 and D 7S516 and exclusion of Jackson-Weiss and Crouzon syndrome loci from 7p. Genomics 1994; 19: 115-119. 
5 L ewanda A F, G reen ED, Weissenbach J et al: E vidence that the Saethre-Chotzen syndrome locus lies between D 7S664 and D 7S507, by genetic analysis and detection of a microdeletion in a patient. A m J Hum G enet 1994; 55: 1195- 1201.

6 M a H W, Lajeunie E, de Parseval N, M unnich A, R enier D, Le Merrer $M$ : Possible genetic heterogeneity in the Saethre-Chotzen syndrome. H um Genet 1996; 98: 228-232.

7 El Ghouzzi V, Le Merrer $M$, Perrin-Schmitt $F$ et al: Mutations of the TWIST gene in the Saethre-Chotzen syndrome. Nat G enet 1997; 15: 42-46.

8 H oward TD, Paznekas WA, G reen ED et al: Mutation in TWIST, a basic helix-loop-helix transcription factor in Saethre-Chotzen syndrome. Nat G enet 1997; 15: 36-41.

9 Thisse B, Stoetzel C, G orostiza-Thisse C, Perrin-Schmitt $F$ : Sequence of the Twist gene and nuclear localization of its protein in endomesodermal cells of early D rosophila embryos. EMBO 」 1988; 7: 2175-2183.

10 Baylies MK, Bate M: Twist: a myogenic switch in D rosophila. Science 1996; 272: 1481-1484.

$11 \mathrm{H}$ ebrok M, Wertz K, Fuchtbauer: M-twist is an inhibitor of muscle differentiation. Dev B iol 1994; 165: 537-544.

12 Chen ZF, Behringer RR: Twist is required in head mesenchyme for cranial neural tube morphogenesis. G enes D ev 1995; 9: 686-699.

13 Stoetzel C, Weber B, B ourgeois P, B olcato-B ellemin A L, Perrin-Schmitt $F$ : Dorso-ventral and rostro-caudal sequential expression of $\mathrm{M}$-twist in the post-implantation murine embryo. M ech D ev 1995; 51: 251-263.

14 Hamamori $Y$, Wu H-Y, Sartorelli V, Kedes L: The basic domain of myogenic basic helix-loop-helix (bHLH) proteins is the novel target for direct inhibition by another bH LH protein, Twist. M ol Cell B iol 1997; 17: 6563-6573.

15 Muenke $M$, Gripp KW, McDonald-MCGinn et al: $A$ unique point mutation in the Fibroblast Growth Factor R eceptor 3 gene (FG FR 3) defines a new craniosynostosis syndrome. A m J H um G enet 1997; 60: 555-564.

16 Golla A, Lichtner P, von Gernet $S$ et al: Phenotypic expression of the fibroblast growth factor receptor 3 (FGFR 3) mutation in a large craniosynostosis family. J M ed G enet 1997; 34: 683-684.

17 R ose CSP, Patel P, R eardon W, M alcom S, Winter R M : The TWIST gene, although not disrupted in Saethre-Chotzen patients with apparently balanced translocations of $7 \mathrm{p} 21$ is mutated in familial and sporadic cases. Hum Mol G enet 1997; 6: 1369-1373.

18 Reardon W, Wilkes D, R utland $P$ et al: Craniosynostosis associated with FGFR 3 pro250arg mutation results in a range of clinical presentations including unisutural sporadic craniosynostosis. J M ed G enet 1997; 34: 632-636.
19 Bourgeois $P$, Stoetzel C, Bolcato-B ellemin A L, M attei M G, Perrin-Schmitt F : The human TWIST gene is located at 7p21 and encodes a b-HLH protein which is $96 \%$ similar to its murine $\mathrm{M}$-twist counterpart. $\mathrm{M}$ amm $\mathrm{G}$ enome 1996; 7: 915-917.

20 Bellus G, Gaudenz K, Zackai EH et al: Identical mutations in three different fibroblast growth factor receptor genes in autosomal dominant craniosynostosis syndromes. Nat G enet 1996; 14: 174-176.

21 Nobukuni Y, Watanabe A, Takeda K, Skarka A, Tachibana $M$ : A nalyses of loss-of-function mutations in the MITF gene suggest that haploinsufficiency is a cause of Waardenburg syndrome type $2 \mathrm{~A}$. A m J H um G enet 1996; 59: 76-83.

22 M urre C, M CCaw PS, Baltimore D: A new DNA binding and dimerization motif in immunoglobulin enhancer binding, daughterless, M yoD, and myc proteins. Cell 1989; 56: 777-783.

23 Lassar A B, D avis R L, W right WE et al: F unctional activity of myogenic $\mathrm{HLH}$ proteins requires hetero-oligomerization with E12/E 47-like proteins in vitro. Cell 1991; 66: 305-315.

24 Voronova A, Baltimore D: M utations that disrupt D NA binding and dimer formation in the $\mathrm{E} 47$ helix-loop-helix protein map to distinct domains. Proc Natl A cad Sci USA 1990; 87: 4722-4726.

25 R ose CSP, M alcolm S: A TWIST in development. Trends G enet 1997; 13: 384-387.

26 K rebs I, Weis I, H udler $M$ et al: Translocation breakpoint maps $5 \mathrm{~kb} 3^{\prime}$ from TWIST in a patient affected with Saethre-Chotzen syndrome. Hum Mol Genet 1997; 6: 1079-1086.

27 Fantes J, Redeker B, Breen $M$ et al: A niridia-associated cytogenetic rearrangements suggest that a position effect may cause the mutant phenotype. $\mathrm{H}$ um M ol G enet 1995; 4: 415-422.

28 Vortkamp A, G essler M , G rezschick K H : G L I 3 zinc finger gene interrupted by translocations in $\mathrm{G}$ reig syndrome families. N ature 1991; 352: 539-540.

29 Wagner T, Wirth J, M eyer J et al: A utosomal sex reversal and campomelic dysplasia are caused by mutations in and around the SRY-related gene SOX 9. Cell 1994; 79: $1111-1120$.

30 Casal J, Leptin $M$ : Identification of novel genes in $D$ rosophila reveals the complex regulation of early gene activity in the mesoderm. Proc Natl A cad Sci USA 1996; 93: 10327-10332. 